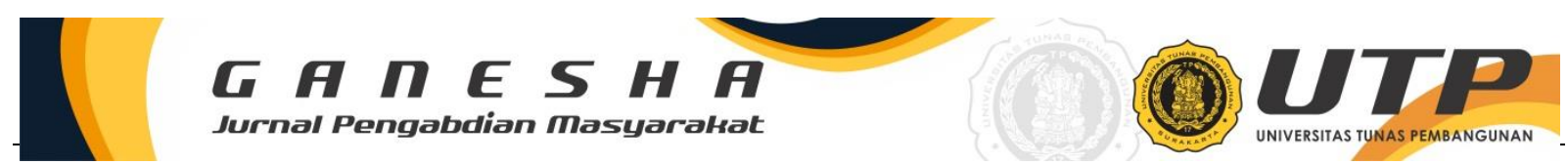

\title{
Pendampingan Perencanaan Pembangunan Pelebaran Jembatan Bibis Luhur RW 022 Nusukan Banjarsari Surakarta
}

\author{
Reki Arbianto*1, Teguh Yuono ${ }^{2}$, Tri Hartanto ${ }^{3}$, Rasyiid Lathiif Amhudo ${ }^{4}$, Gunarso ${ }^{5}$ \\ 1,2,3,4,5 Universitas Tunas Pembangunan (UTP) Surakarta \\ *e-mail: reki.arbianto@lecture.utp.ac.id
}

\begin{abstract}
Abstrak
Bibis Luhur merupakan salah satu kampung di kelurahan Nusukan, kecamatan Banjarsari, kota Surakarta. Kampung Bibis Luhur terdapat sebuah jembatan tepatnya di RW 022 yang menghubungkan antar RW. Kondisi jembatan sekarang ini dirasakan sudah sempit karena pertumbuhan jumlah kendaraan dan lalu lintas harian yang melaluinya. Oleh sebab itu dengan dorongan dari masyarakat warga RW 022 maka jembatan ini akan diperlebar, untuk menunjang aktifitas warga sekitar. Tahapan yang dilakukan pada pendampingan kali ini dibagi menjadi 2 tahap yaitu tahap persiapan dan tahap pelaksanaan. Pada kegiatan persiapan dilakukan diskusi dan koordinasi dengan perangkat kampung Bibis Luhur RW 022 dan warga sekitar guna memberikan masukan yang bersifat membangun untuk kegiatan ini sedangkan pada tahap pelaksanaan dilakukan pengukuran sampai dengan penggambaran detail desain guna memperkirakan besarnya anggaran biaya untuk pekerjaan pembangunan pelebaran jembatan Bibis Luhur RW 022, Kel. Nusukan, Kec. Banjarsari Surakarta. Berdasarkan hasil pendampingan dihasilkan gambar struktur dan Rencana Anggaran Biaya untuk pembangunan pelebaran jembatan Bibis Luhur RW 022, Kel. Nusukan, Kecamatan Surakarta adalah sebesar Rp 20.300.000,00. Hasil detail desain dan analisa biaya tersebut untuk selanjutnya dapat digunakan sebagai dasar dalam pelaksanaan pekerjaan konstruksi.
\end{abstract}

Kata kunci: Bibis Luhur RW 22, jembatan, gambar struktur, RAB

\begin{abstract}
Bibis Luhur is one of the villages in the Nusukan village, Banjarsari sub-district, Surakarta city. Kampung Bibis Luhur has a bridge to be precise at RW 022 which connects between RWs. The current condition of the bridge is felt to be narrow due to the growth in the number of vehicles and daily traffic passing through it. Therefore, with the encouragement of the residents of $R W 022$, this bridge will be widened, to support the activities of local residents. The stages carried out in this mentoring are divided into 2 stages, namely the preparation stage and the implementation stage. During the preparatory activities, discussions and coordination with the village staff of Bibis Luhur RW 022 and local residents were carried out to provide constructive input for this activity, while at the implementation stage measurements were carried out up to a detailed description of the design in order to estimate the amount of the budget for the construction work of the Bibis Luhur RW bridge widening. 022, Ex. Nusukan, Kec. Banjarsari Surakarta. Based on the results of the assistance, a structure drawing and a Budget Plan for the construction of the Bibis Luhur RW 022 bridge widening, Kel. Nusukan, Surakarta District, is IDR 20,300,000.00. The results of the detailed design and cost analysis can then be used as a basis for the implementation of construction work.
\end{abstract}

Keywords: Bibis Luhur RW 022, bridge, structure drawing, BOQ

\section{PENDAHULUAN}

Bibis Luhur merupakan salah satu kampung di kelurahan Nusukan, kecamatan Banjarsari, Kota Surakarta. Nama 'Nusukan' sudah ada sejak era kejayaan Mangkunegaran. Nama tersebut diambil dari kondisi kewilayahan daerah ini yang terletak di samping Kali Anyar yang dibangun pada masa Mangkunegaran di mana aliran airnya dibuat menusuk langsung terhadap aliran Bengawan Solo untuk mengantisipasi datangnya banjir, sehingga kata "menusuk" ini berkembang menjadi nama wilayah kelurahan Nusukan seperti saat ini. Kampung Bibis Luhur terdapat sebuah jembatan tepatnya di RW 22 yang menghubungkan antar RW. Kondisi jembatan sekarang ini dirasakan sudah sempit karena pertumbuhan jumlah kendaraan dan lalu lintas harian yang melaluinya. Oleh sebab itu dengan dorongan dari 
masyarakat warga RW 22 maka jembatan ini akan di perlebar, untuk menunjang aktifitas warga sekitar. Adapun lokasi jembatan tersebut di tunjukkan pada gambar sebagai berikut:

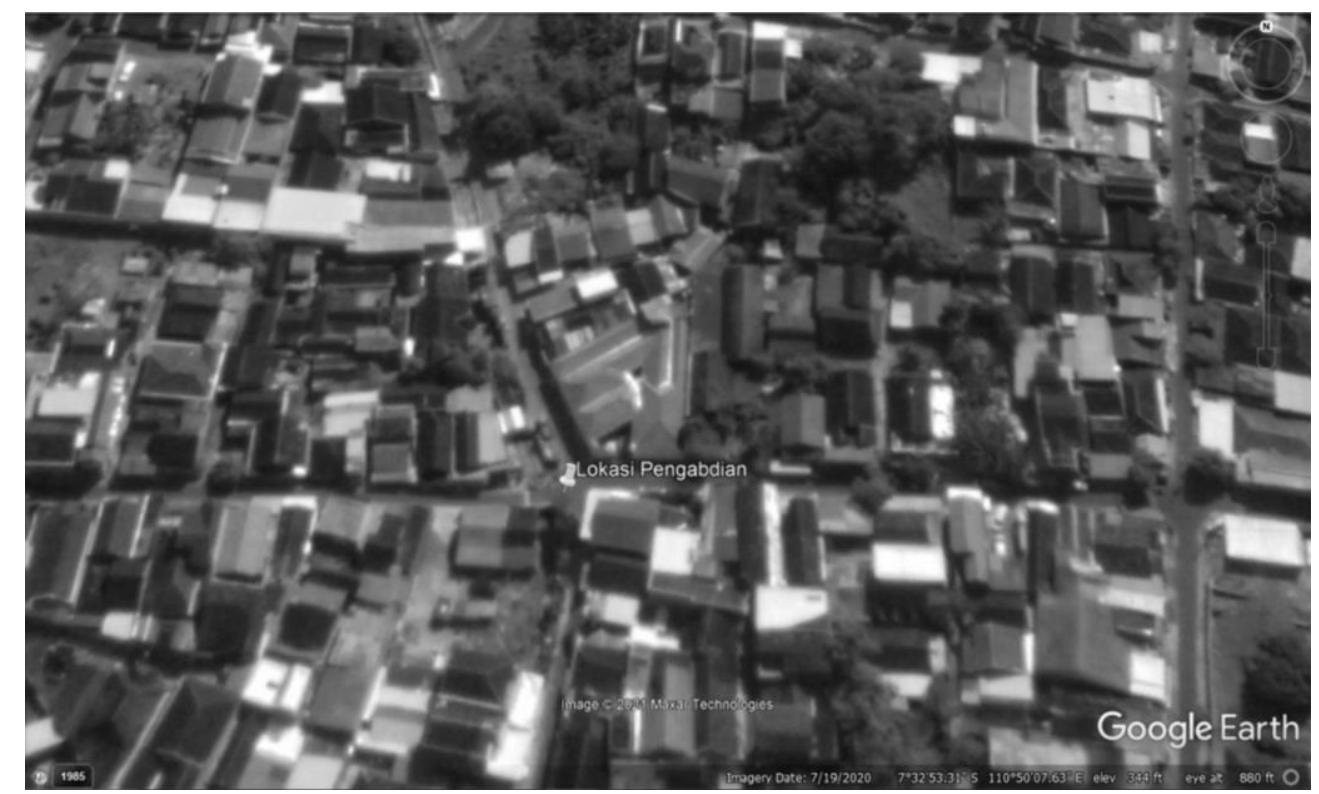

Gambar 1. Lokasi Pengabdian

Adapun tujuan dilakukan pengabdian kepada masyarakat untuk Pendampingan Perencanaan Pembangunan Pelebaran Jembatan Bibis Luhur RW 22 Kelurahan Nusukan, Kecamatan Banjarsari, Surakarta, yaitu dapat mengurai serta memberikan solusi terbaik dari problem yang terjadi di lapangan. Sedangkan manfaat yang dapat diperoleh dari kegiatan ini adalah dapat meringankan beban perangkat kampung Bibis Luhur dan warga RW 22 khususnya dalam menyelesaikan permasalahan yang ada demi kepentingan masyarakat di sekitar lokasi kegiatan pengabdian.

\section{METODE}

Pelaksanaan pengabdian kepada masyarakat dilaksanakan dengan 2 tahapan yaitu: Tahap persiapan, yaitu melakukan diskusi dengan perangkat kampung Bibis luhur, pengurus RW 022 dan perwakilan warga tentang rencana pelaksanaan pengabdian masyarakat oleh tim dosen. Berdasarkan hasil diskusi tersebut diharapkan akan diperoleh informasi secara benar dan akurat. Diskusi tersebut juga berguna untuk menentukan langkah berikutnya demi terwujudnya kondisi yang diharapkan. Setelah diskusi dilakukan maka akan segera direncanakan langkah-langkah dalam pengambilan data di lapangan bersama dengan perangkat kampung terkait otoritas wilayah. Posisi tim pengabdian masyarakat (dosen) hanya sebagai konsultan yang tidak mempunyai kewenangan memutuskan. Otoritas tim pengabdian masyarakat (dosen) hanya memberikan saran dan usulan yang bersifat membangun dalam koridor rasional dan terukur.

Tahap Pelaksanaan, kegiatan yang dilaksanakan meliputi: (a) Melakukan kompilasi data pengukuran, dokumentasi foto, dan lain-lain sebagai bahan untuk proses analisis. (b) Melakukan analisis tapak terhadap kondisi tapak lokasi rencana pembangunan pelebaran jembatan. (c) Membuat gambar pra-desain berupa gambar site-plan, denah, dan potongan jembatan. (d) Dari bahan pra-desain yang telah disusun, dilakukan diskusi dengan semua tim 
dan calon pengguna untuk mendapatkan masukan dan saran untuk perbaikan pra-desain. (e) Setelah mendapat persetujuan gambar pra-desain maka dibuat perhitungan struktur gambar detailnya untuk gambar pelaksanaan konstruksi. (f) Penyusunan gambar detail untuk pelaksanaan konstruksi. (g) Penyusunan analisa yang diperlukan sebagai pendukung. (h) Penyusunan perkiraan rencana anggaran biayanya (RAB).

Kegiatan pelaksanaan pengabdian ini harus diimbangi dengan partisipasi dari mitra terkait dalam hal ini perangkat kampung Bibis Luhur, pengurus RW 22 dan masyarakat sekitar. Adapun perannya yaitu sebagai tempat bertukar pendapat (diskusi) dan sebagai tim pelaksana dalam rencana pembangunan pelebaran jembatan tersebut.

\section{HASIL DAN PEMBAHASAN}

Survei pendahuluan merupakan kegiatan untuk mendapatkan informasi dan data awal yang diperlukan di lokasi pengabdian yang nantinya akan berguna untuk analisis lebih lanjut. Survei pendahuluan untuk pengabdian ini harus melalui beberapa tahapan seperti berikut.

(a)Tahap perijinan, sebelum melakukan survei pendahuluan, tim pengabdian akan memberikan surat tugas terlebih dahulu ke perangkat desa terkait dan pengurus terkait.

(b)Survei lokasi, setelah menyerahkan surat tugas, maka tim merencanakan untuk melakukan survei lokasi.
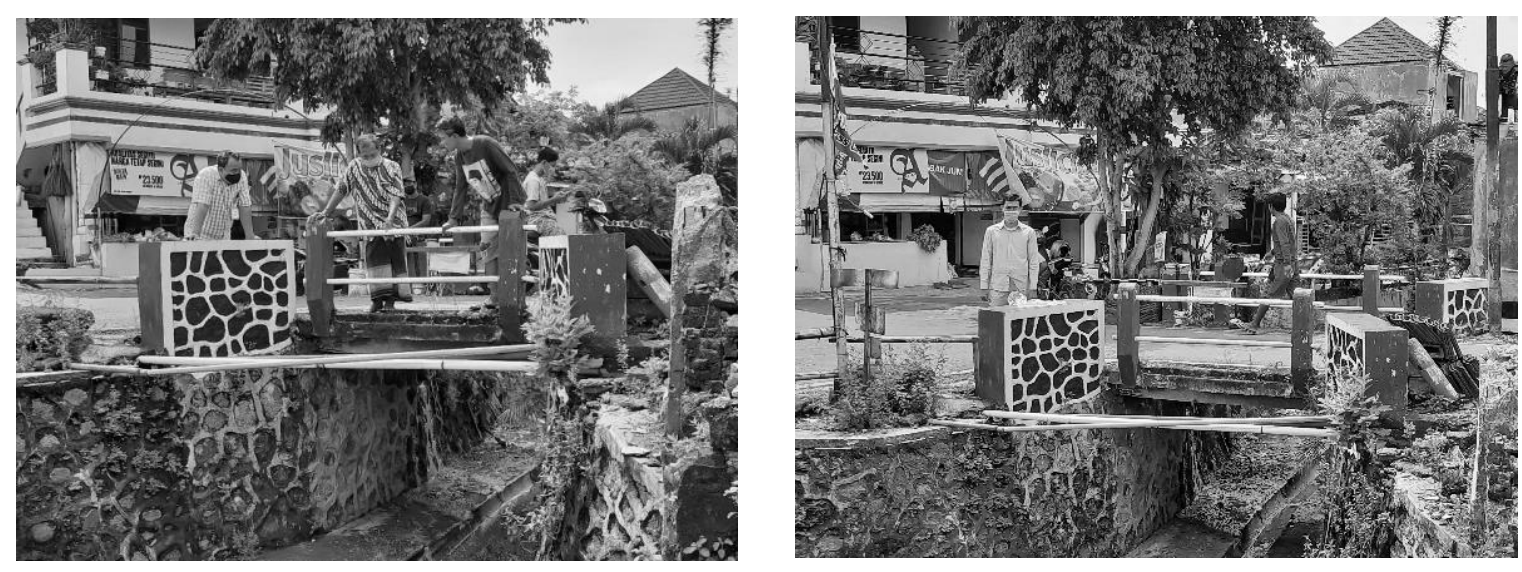

Gambar 2. Survey Lokasi

Berdasarkan survei pendahuluan maka telah dilakukan beberapa kegiatan seperti: Melakukan kompilasi data pengukuran, dokumentasi foto, dan lain-lain sebagai bahan untuk proses analisis. Melakukan analisis tapak terhadap kondisi eksisting lokasi rencana pembangunan pelebaran jembatan. Melakukan analisis pekerjaan yang sesuai dengan kebutuhan. Membuat gambar pra-desain berupa gambar site-plan, denah, dan potongan. Dari bahan pra-desain yang telah disusun, dilakukan diskusi dengan semua tim dan calon pengguna untuk mendapatkan masukan dan saran untuk perbaikan pra-desain. Setelah mendapat persetujuan gambar pra-desain maka dibuat perhitungan struktur gambar detailnya untuk gambar pelaksanaan konstruksi. Penyusunan gambar detail untuk pelaksanaan konstruksi. Penyusunan analisa yang diperlukan sebagai pendukung. Penyusunan perkiraan rencana anggaran biayanya (RAB). Dalam proses survei dan perencanaan tidak terdapat kendala dan berjalan lancar dikarenakan adanya kerjasama yang baik antara tim pengabdian, warga sekitar dan perangkat desa. 
GANESHA: Jurnal Pengabdian Kepada Masyarakat Vol. 1, (2) Desember 2021

Adapun gambar struktur yang dihasilkan adalah sebagai berikut:

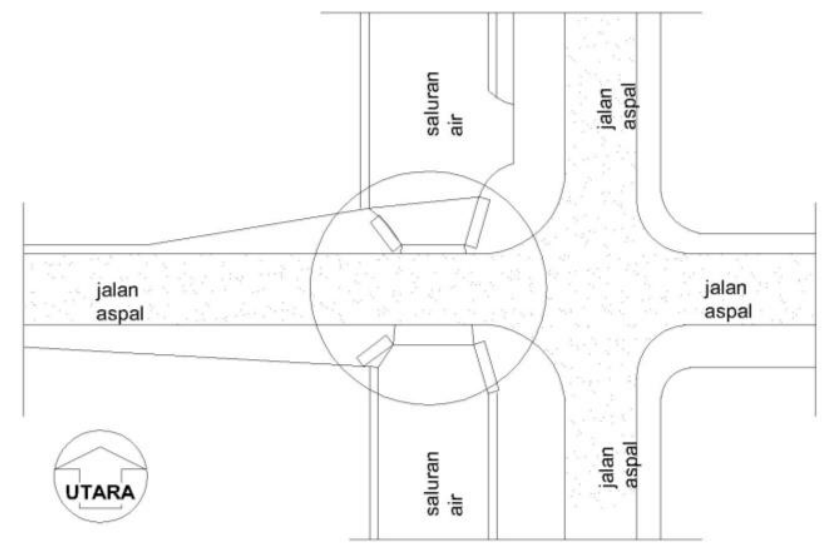

Gambar 3. Site Plan Jembatan

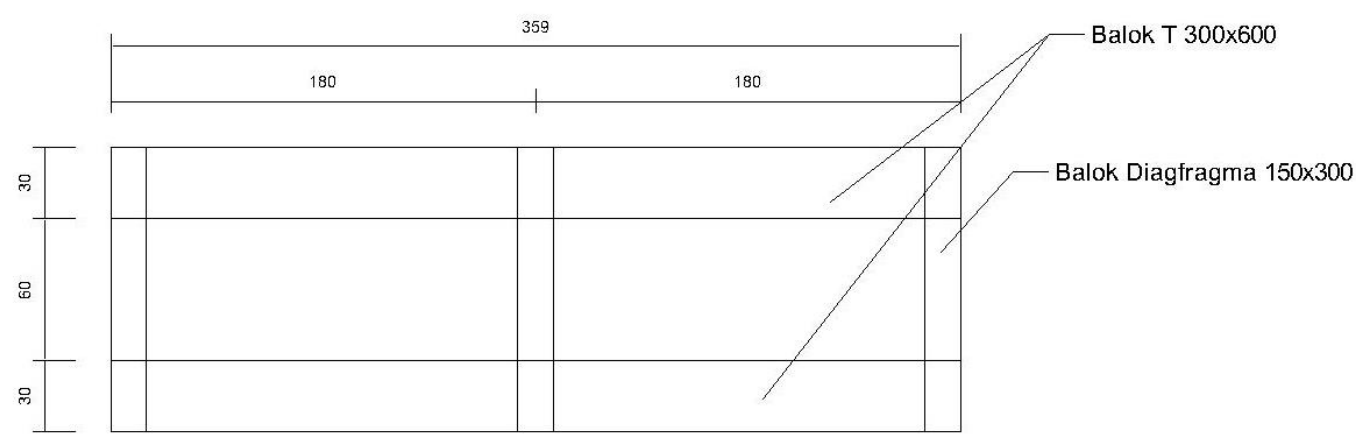

Gambar 4. Denah Pembalokan Jembatan
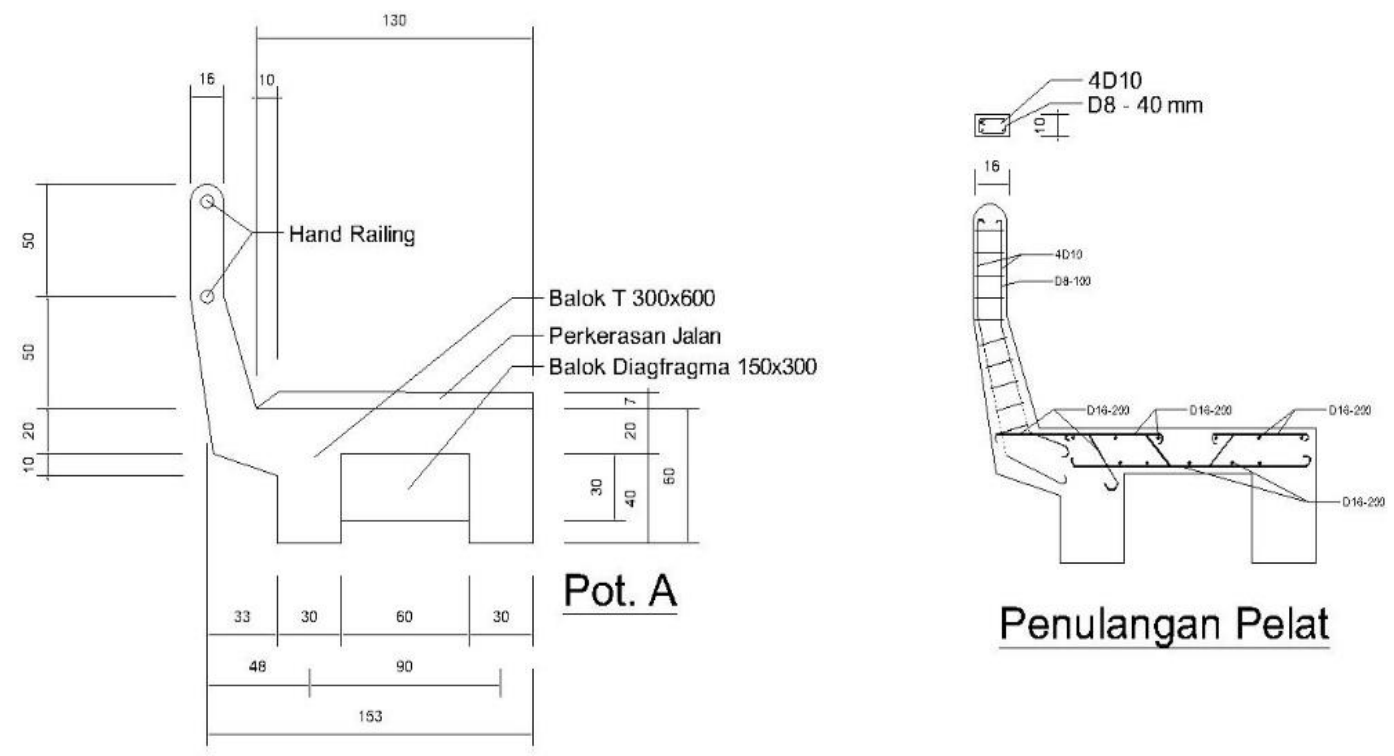

Penulangan Pelat

Gambar 4. Detail penulangan pelat 


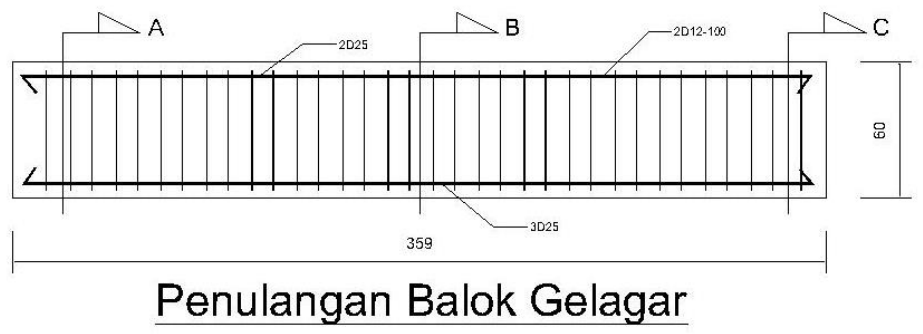

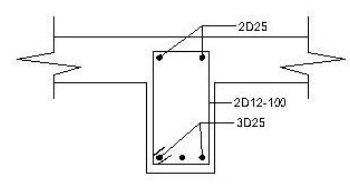

Pot. A

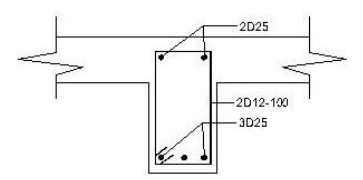

Pot. B

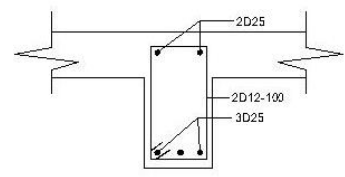

Pot. C

Gambar 4. Detail penulangan Balok Gelagar

Berdasarkan gambar denah dan detail potongan tersebut di atas, maka item yang direncanakan bersama dengan mitra dapat dilihat seperti pada tabel rencana anggaran biaya berikut:

Tabel 1. Rencana Anggaran Biaya

\begin{tabular}{ccc}
\hline No & Uraian Pekerjaan & Jumlah \\
\hline A & Pekerjaan Persiapan & Rp. 1.500.000,- \\
B & Pekerjaan Fisik Jembatan & Rp. 18.773.477,- \\
\hline Jumlah Total & & Rp. 20.273.477,- \\
\hline Pembulatan & Rp.20.300.000,- \\
\hline
\end{tabular}

\section{KESIMPULAN}

Tim pengabdian kepada masyarakat telah melaksanakan pendampingan dalam melakukan perencanaan pembangunan pelebaran jembatan Bibis Luhur RW 022 kelurahan Nusukan, kecamatan Banjarsari, Surakarta. Untuk kegiatan ini dapat diketahui besarnya rencana anggaran biaya untuk kegiatan ini adalah sebesar Rp 20.300.000,00. Kegiatan pendampingan ini akan lebih sempurna apabila pelaksanaan kegiatan yang nantinya dilakukan mengikuti item-item yang telah direncanakan serta dilakukan pengawasan dalam pelaksanaan pekerjaan tersebut agar hasil pembangunan pelebaran jembatan ini sesuai dengan perencanaan. 


\section{UCAPAN TERIMA KASIH}

Penulis mengucapkan terima kasih kepada perangkat kampung Bibis Luhur RW 022 dan warga yang terlibat dalam pengabdian dan memberi dukungan terhadap pengabdian ini.

\section{DAFTAR PUSTAKA}

Badan Pertanahan Nasional. (1998). Petunjuk Teknis Peraturan Menteri Negara Agraria/Kepala BadanPertanahan Nasional no 3 Tahun 1997 Materi Pengukuran dan Pemetaan Pendaftaran Tanah. Badan Pertanahan Nasional Republik Indonesia.

Badan Pusat Statistik. (2020). Kabupaten Klaten Dalam Angka 2020. Badan Pusat Statistik.

Badan Pusat Statistik. (2019). Kecamatan Banjarsari Dalam Angka 2019. Badan Pusat Statistik.

Handoyo, Suryo \& Yuono, Teguh. 2020. "Pendampingan Revitalisasi Lapangan Desa Ngabeyan Kecamatan Kartasura Kabupaten Sukoharjo. IJECS. Vol.1, No.1. Sukoharjo. UNIVET

Mukomuko, Ir.J.A. (1985). Dasar Penyusunan Anggaran Biaya Bangunan. Jakarta, Gaya Media Pratama.

Rochmanhadi, (1993). Perhitungan Biaya Pelaksanaan Pekerjaan dengan Menggunakan Alat-alat Berat. Cetakan ke-2 Jakarta: Yayasan Badan Penerbit Pekerjaan Umum.

Setiawan, A. (2016). Perancangan Struktur Beton Bertulang Berdasarkan SNI 2847:2013. Jakarta: Erlangga.

Yuono, Teguh \& Mulyandari, Erni. 2021. "Pendampingan Perencanaan Jalan Lingkungan Di Kelurahan Jayengan Kecamatan Serengan Kota Surakarta. Vo1.1, No.1. Ganesha. Surakarta. UTP

https://upload.wikimedia.org/wikipedia/id/4/43/Nusukan 